\title{
Tüketicileri Sosyal Sorumlu Tüketime Yönlendiren Faydacı ve Hedonik Güdülerin İncelenmesi
}

\author{
Investigation of Utilitarian and Hedonic Motives Directing Consumers to Socially \\ Responsible Consumption
}

\author{
Doç. Dr. Şükran KARACA ${ }^{\text {ID } 1}$, Arş. Gör. Dr. İbrahim YEMEZ ${ }^{\text {ID }} 2$
}

\begin{abstract}
$\ddot{O} \mathbf{z}$
Giderek artan çevresel ve sosyal problemler dünyanın dört bir yanındaki insanların lüks yaşam tarzlarının ve sorumsuz tüketiminin dünyayı tahrip ettiği gerçeğinin fark edilmesini sağlamıștır. Dolayısıyla her geçen gün sorumlu tüketime yönelik bilinç artmaktadır. Bu bağlamda bu çalışmanın amacını faydacı ve hedonik tüketimin sosyal sorumlu tüketim davranışı üzerindeki etkisini ortaya koymak oluşturmaktadır. Bu amaçla Sivas ili şehir merkezinde yaşayan, kolayda örnekleme metoduyla belirlenen, 18 yaşından büyük 413 kişiyle yüz yüze anket tekniği kullanılarak veriler toplanmıştır. Verilere ilk olarak AMOS programıyla Doğrulayıcı Faktör Analizi uygulanmıştır. Daha sonra araştırmacılar tarafindan tasarlanan model Yol Analizi ile test edilmiştir. Analiz sonuçlarına göre faydacı tüketim ve hedonik tüketim arasından pozitif ve anlamlı bir korelasyon ilişkisi vardır. Ayrıca faydacı tüketim sosyal sorumlu tüketim ve alt boyutlarını pozitif ve olumlu anlamda etkilerken; hedonik tüketim ise sosyal sorumlu tüketim ve alt boyutları üzerinde anlamlı bir etkiye sahip değildir.
\end{abstract}

Anahtar Kelimeler: Sosyal sorumlu tüketim, faydacı tüketim, hedonik tüketim, rasyonel tüketim

Makale Türü: Araştırma

\begin{abstract}
Increasingly, environmental and social problems have led to the realization that the luxury lifestyles and irresponsible consumption of people all over the world have destroyed the world. Therefore, consciousness for responsible consumption increases day by day. In this context, the aim of this study is to reveal the effect of utilitarian and hedonic consumption on the socially responsible consumption behavior. For this purpose, data were collected by using face-to-face survey technique with 413 people older than 18 years, who were living in the city center of Sivas and were determined by easy sampling method. Confirmatory Factor Analysis was applied to the data with AMOS program. The model designed by the researchers was then tested with Path Analysis. According to the results of the analysis, there is a positive and significant correlation between beneficiary consumption and hedonic consumption. In addition, beneficiary consumption positively and positively affects socially responsible consumption and sub-dimensions; Hedonic consumption has no significant effect on socially responsible consumption and sub-dimensions.
\end{abstract}

Keywords: Socially responsible consumption, beneficial consumption, hedonic consumption, rational consumption

Paper Type: Research

sSivas Cumhuriyet Üniversitesi, Turizm Fakültesi, sukrankaraca@gmail.com.
${ }^{2}$ Sivas Cumhuriyet Üniversitesi, İ̈BF, ibrahimyemez@hotmail.com.

Atıf için (to cite): Karaca, Ş. ve Yemez, İ. (2020). Tüketicileri sosyal sorumlu tüketime yönlendiren faydaci ve hedonik güdülerin incelenmesi, Afyon Kocatepe Üniversitesi Sosyal Bilimler Dergisi, 22(3), 771-785. 


\section{Giriş}

Son yıllarda nüfusun hızlı artışı, doğal kaynakların bilinçsizce kullanımı, artan tüketim ve çevre kirliliğine bağlı olarak sosyal sorumlu tüketim kavramı ortaya çıkmıştır. Hem çevreye hem de sosyal sorunlara karşı daha hassas olan bireyler, bu hassasiyetlerini gösterecek şekilde tüketim yapma eğilimindedirler ve bu davranışları sosyal sorumlu tüketim davranışı olarak ifade edilmektedir (Sayraç, 2016, s.1). Sosyal sorumlu tüketimin temel başlangıç noktası bireylerin kendi kişisel tüketimlerinin toplum üzerindeki etkisini ve sonuçlarını düşünmesidir (FrancoisLecompte ve Roberts, 2006, s.50). Sorumlu tüketim, daha azıyla daha fazla ve daha iyisini yapmak, tüm yaşam döngüsü boyunca kaynak kullanımını, çevresel bozulmayı ve kirliliği azaltarak ekonomik faaliyetlerden net refah kazanımlarını artırmak anlamına gelmektedir (Castano, 2016, s.460). Francois-Lecompte ve Roberts (2006, s.52) 'in ifade ettiği gibi sosyal sorumlu tüketim; fiziksel çevre ve / veya sosyal kaygıları ifade etmek için satın alma gücünün kullanımı üzerinde olumlu veya daha az olumsuz bir etkiye sahip olduğu algılanan ürün ve hizmetleri satın almayı içermektedir. Bu tanım, kurumsal sosyal sorumluluk kavramıyla tutarlıdır ve sosyal olarak sorumlu tüketici, satın alımından etkilenebilecek paydaşların refahını düşünen bir kişidir. Webb vd. ise (2008, s.91), sosyal sorumlu tüketiciyi "herhangi bir zararlı etkiyi en aza indirgemek veya ortadan kaldırmak ve topluma uzun vadeli yararı en üst seviyeye çıkarmak için bir istek üzerine" ürünlerini satın alma, kullanma ve elden çıkarmaya dayanan bir kişi olarak tanımlamışlardır.

Mal ve hizmetlerin doğrudan ve dolaylı olarak tüketimi birçok sosyal ve çevresel sorunlara neden olmaktadır. Çevresel sorunların bir kısmı ise tüketicilerin yaşam tarzları ile ilgilidir. Tüketiciler davranışlarında, tutumlarında ve değerlerinde gerekli değişiklikleri yapmadıkları sürece daha sürdürülebilir yaşam tarzlarına ulaşılması da mümkün olmamaktadır. Tüketicilerin özellikle satın alma kararlarında etik ilkeleri dikkate almaları daha bilinçli tüketime yol açmaktadır (Roberts, 1996, s.80). Tüketicilerin yaptıkları her seçimin çevre ve toplum üzerinde etkileri vardır. Sosyal sorumlu tüketici yaptığ 1 seçimler ile dünyayı değiştirecek güce sahiptir. Olumsuz çevresel ve sosyal etkileri daha az olan ürünleri seçmek sosyal sorumlu tüketicinin görevidir (https://equiterre.org). Sürdürülebilirlik ve sosyal sorumluluk kavramlarının giderek birbirini tamamlaması ve ayrılmaz birer bütün haline gelmesi, sürdürülebilir tüketim düşüncesinin ve buna bağlı olarak da bireylerin sosyal sorumluluğunun ortaya çıkmasında önemli rol oynamıştır (Şüküroğlu, 2018, s.453).

Yapılan literatür incelemesi sonucunda hem hedonik hem de faydacı tüketici davranışının sosyal sorumlu tüketimin öncülleri olduğu varsayılmaktadır. Ancak Adomaviciute (2013, s.757), hedonik tüketici davranışlarının sosyal sorumlu tüketimin özellikle etik yönünde faydacı tüketici davranışlarından daha fazla etkiye sahip olduğunu ifade etmektedir. Tüketici davranışları geleneksel pazarlama dönemlerinde rasyonel ihtiyaca dönük iken modern pazarlama dönemlerinde ise daha çok haz almaya dönük davranışlar içerisindedir. Tüketicilerin zevk almaya dönük takındığı tutum beraberinde hedonik(hazcı) tüketim kavramını ortaya çıkarmıştır (Hirschman ve Holbrook, 1982, s.93). Bu bağlamda bu çalışmanın amacı sosyal sorumlu tüketim ile faydacı ve hedonik tüketici davranışı arasındaki iliş̧inin incelenmesidir.

\section{Sosyal Sorumlu Tüketim ile Faydacı ve Hedonik Güdüler Arasındaki İlişki}

Tüketiciler hedonik (duyusal nitelikler) ve faydacı değerlerden (işlevsel niteliklerden) dolayı mal ve hizmet satın almakta ve tüketim davranışını gerçekleştirmektedirler (Adomaviciute, 2013, s.756). Hedonik değer; zevk, eğlence, fantezi ve duyuların memnuniyeti ile ilişkilidir (Holbrook ve Hirschman, 1982, s.132) ve genel olarak anlık memnuniyet, egoizm, bireyselci materyalizm ve aşırı bencil davranış ile bağlantılı olumsuz çağrışımlarla ifade edilmektedir (Szmigin ve Carrigan, 2006, s.610).

Hedonizm felsefesi, insan davranışının acıdan kaçınma ve haz duyduğu faaliyetlere yönelme düşüncesi üzerine kurulmuştur. Buna göre, birey kendisini kendi ölçülerine göre yaptığ1 
ihtiyaç tanımından yola çıkarak yarattığı ruhsal gerilimi azaltmak amacıyla birtakım ürünleri kullanma/tüketme yönünde davranış sergilemektedir. Epikür (M.Ö 341-270)'ün ifade ettiği türden bir hedonizmi savunan sadelik anlayışının özellikle bireyin içsel huzura kavuşmasında, yaşamını her yönüyle sadeleştirmesinde ve çevrenin korunmasında bireysel ve toplumsal açıdan faydalı olduğu düşünülmektedir (Özgül, 2011, s.36). Etik tüketiminde kendi içinde hedonistik bir yönü olduğu ifade edilmektedir. Bu bakımdan hedonizm, bireyin "iyi yaşam” için çaba gösterme motivasyonuna dayanmaktadır. "İyi yaşam", bir bireyin alternatif tüketim uygulama biçimlerini seçme eğilimi ile sonuçlanan tüketimcilik ve materyalizmden hoşnutsuzluğunu ifade etmektedir. Dolayısıyla, hedonizm kavramı göz önüne alındığında, egoist ve etik hedonizm şeklinde iki hedonizm şeklini analiz etmek gerekmektedir. Egoist hedonizm, bireyin mutluluğu veya zevkinin nihai amaç olduğu fikrine dayanmaktadır (Sidgwick, 1981'den akt., Adomaviciute, 2013, s.756). Yani, egoist hedonistlerin başkalarının refahı ile ilgilenmediği sonucuna ulaşlabilir. Etik hedonistler ise sadece kendi iyilikleriyle değil, başkalarının refahı ile de ilgilenmektedirler. Etik hedonizm kavramı, zevkli bir hareket olarak etik ürünlerin satın alınması ve tüketilmesiyle ilgilidir. Hedonizm, "doğru şeyi” yapmanın kişinin zevk hissine verdiği öz saygı ile ilişkili olabileceği kabul edilirse, etik tüketimin meşru bir boyutu olabilir (Szmigin ve Carrigan, 2006, s.610). Dolayısıyla gerek gönüllü sadelik gerek etik tüketim ve gerekse diğer sosyal sorumlu tüketim alt boyutlarının (yeşil tüketim, sürdürülebilir tüketim vd.) hedonizm ile ilişkili olduğu söylenilebilir.

Faydacı değer ise, doğru ürünü elde etmek için doğru fiyat ve minimum çaba ile ilişkilidir (Babin, 1994, s.646). Faydacı değerde, tüketiciler tüketim değerini dikkate almaktadır ve faydacı tüketimin amacı, tüketiciye en yüksek faydayı sağlamaktır (Irani ve Hanzaee, 2011, s.36). Bir satın alma davranışı olan faydacı davranış ise; tüketici alışveriş sırasında ve sonrasında göreve odaklı, rasyonel bir tutum içerisinde ve faydacı bir değer arayışı içindedir (Carpenter vd., 2005, s.44). Faydacı tüketim yapmak isteyen bir tüketici için öncelikle ihtiyaç ortaya çıkar ve tüketici bütçesine en uygun mal veya hizmeti alternatifleri karşılaştırarak satın alır. Bu durum fayda teorisi olarak ifade edilmektedir (Buhrman, 2002, s.79-81). Dolayısıyla bireylerin sadece ihtiyac1 olan ürünleri ihtiyacı kadar satın alması, ürünlerin çevreye zararlı etkilerini hesaba katması, sağlığına zarar vermeyecek ürünleri seçmesi, yaptığı tüketim sonucunda sadece kendi çıkarlarını değil toplumun çıkarlarını da düşünmesi gibi rasyonel güdülerin tüketicileri sorumlu tüketime yönlendirdiği ifade edilebilir.

Hedonik ve faydacı tüketim ile ilgili verilen kararlarda oto kontrol ve suçluluk hissinin de rolü vardır. Suçluluk, genellikle ahlaki standartlara ilişkin duyulan kaygı veya başkalarına verilen zararı içermektedir (Tangney ve Dearing, 2002). Suçluluk duygusu; satın alma sırasında, kullanım sırasında ve ürünleri kullandıktan sonra da ortaya çıkabilmektedir (Dahl vd., 2003, s.159). Hedonik ürünler daha fazla suçluluk hissettirmekte ve faydacı ürünlerin tüketimini haklı çıkarmayı daha kolaylaştırmaktadır. Bireylerin hedonik ürün satın almaktan dolayı hissettikleri suçluluk duygusu arttıkça, hedonik tüketim ertelenmekte ve faydacı tüketim oto kontrolün etkisi ile güçlü olmaktadır (Urminsky ve Kivetz, 2004, s.359).

Sosyal sorumlu tüketim konusundaki çalışmalar artmasına rağmen özellikle bireyleri sosyal sorumlu tüketime yönlendiren güdüler hakkında yapılmış çok fazla çalışma mevcut değildir. Bundan dolayı bu çalışma ile sosyal olarak sorumlu tüketiciyi ifade eden yeni bilgilerin bulunmasına katkı sağlanacağı düşünülmektedir.

\section{Literatür Analizi}

Literatürde sosyal sorumlu tüketim davranışları olarak; etik tüketim, sürdürülebilir ve çevre dostu tüketim, yeşil tüketim ve tüketici vatandaş sorumluluğu sayılabilir (Dursun vd., 2016, s.15-17). Aynı zamanda sosyal sorumlu tüketim davranışına ilişkin literatür incelendiğinde, pek çok çalışmada etik ve çevreci tüketim davranışının sorumlu tüketim davranışının bir alt boyutu olarak yer aldığını görmek mümkündür (Buğday, 2015, s.70). 
Etik tüketim; bir ürünün satın alınmasında belirli etik konularda ilgili olunması ve buna uygun olarak özgürce seçim yapılması (Süygün, 2015, s.56) olarak ifade edilebilir. Tüketicilerin etik tüketim tarzlarını belirlemek için yapılan araştırmalarda, bireylerin faydacı ve hedonik yönlerinin dikkate alındığı görülmektedir. Wilkes (1978, s.70-71) tarafından ev hanımlarına yönelik yapılan çalışmada, hileli tüketici davranışlarını içeren ankette tüketicilerin hileli davranışları genellikle "yanlış" buldukları ifade edilmiştir. Hileli davranışın fiziken kimseye zarar vermediği sürece kabul edilebilir olarak algıladıkları tespit edilirken, bazı davranışlarda hoşgörü noktaları oluştuğu ve bunların işletmelerin hataları olarak ifade edildiği belirtilmiştir. Hedonizm, tüketici ve tüketim ile ilişkisi boyutunda ele alındığında, tüketicinin bencilliği ve duygularını hoş tutmasıyla ilgili bir süreç olarak ifade edildiğinden (Fırat ve Aydın, 2016, s.1841), araştırmada etik olmayan davranışlar hoşgörü noktaları sayesinde kabul edilebilir olarak gösterilmiştir. Sosyal açıdan sorumlu tüketimin etik yönü, yani hangi faktörlerin bireyleri etik olarak tüketime yönlendirdiği ile ilgili çalışmalar az sayıdadır. Bu konu ile ilgili bir çalışma Adomaviciute tarafından yapılmıştır. Adomaviciute (2014, s.758), egoist hedonik tüketici davranışının, suçluluk denilen olumsuz öz-bilinçli duyguların etkisiyle etik ürünlerin satın alınmasına yol açabileceğini, aynı zamanda etik hedonik tüketici davranışının etik tüketim üzerinde doğrudan etkiye sahip olabileceğini varsaymaktadır.

Sürdürülebilir ve çevre dostu tüketim; literatürde kişinin bireysel veya ortak tüketiminin çevresel ve toplumsal sonuçlarını, tüketim öncesinde, sırasında ve sonrasında dikkate almak ya da kendi satın alım gücünü çevresel düzenin korunması ve iyileştirilmesini desteklemek için korumak anlamına gelmektedir (Dursun vd., 2016, s.16). Çabuk ve Nakipoğlu (2003, s.39) tarafından yapılan çalışmada, çevreci ürünlerin farkında olma düzeyi yüksek olan tüketicilerin büyük bir çoğunluğunun aynı zamanda "yüksek çevreci ürün satın alma grubunda" oldukları belirlenmiştir. Saydan ve Kanıbir (2007, s.231) tarafından üniversiteli tüketicilerin çevreci tüketim tutumları ve satın alma davranışlarına etkilerini incelemek amacıyla yapılan çalışmada da; tüketicilerin sahip oldukları çevreci kültür, çevrecilik anlayışının tüketiciler tarafından içselleştirilme düzeyi, tüketicinin çevreci kimliğe sahip olması durumunda bunun yapacağı etki düzeyine ilişkin algılamalar ve tüketicilerin sahip olduğu çevrecilik yönlü inanışlar/bilgiler, çevreci ürün satın almaya yönelik tutumu belirleyen temel bileşenler olarak ifade edilmiştir. $\mathrm{Bu}$ çalışmaların sonuçlarından yola çıkarak, tüketicilerin sürdürülebilir ve çevre dostu tüketim yaparken daha faydacı ve rasyonel davrandıkları söylenebilir.

Yeşil tüketim; tüm satın alma, kullanma ve atma sürecinde, özellikle çevre dostu ürünler satın alma aşamasında, tüketimin çevre üzerindeki olumsuz etkisini en aza indiren bir tür tüketim davranışını ifade eder (Pagiaslis ve Krontalis, 2014, s.336). Aksoy ve Erdoğan (2008, s.596) tarafından yeşil tüketim yapan tüketicilerin özelliklerini belirlemek amacıyla yapılan çalışmada; bireylerin yeşil tüketici olduklarını söylemelerine rağmen yeşil tüketim kültürünün henüz benimsemedikleri sonucuna ulaşılmıştır. Bu sonuç tüketicilerin yeşil tüketim davranışlarında faydacı güdülerden ziyade hedonistik güdüler ile hareket ettiğini göstermektedir. Aynı çalışmada, yeşil tüketiciler ile eğitim ve gelir değişkeni arasında herhangi bir anlamlı ilişki bulunamaz iken özellikle genç ve bekâr tüketicilerin yeşil tüketici olmadıkları ortaya çıkmıştır.

Mohr vd. (2001, s.45) sosyal açıdan sorumlu tüketiciyi, herhangi bir zararlı etkiyi en aza indirmek ya da ortadan kaldırmak ve toplum üzerindeki uzun vadeli faydalı etkiyi en üst düzeye çıkarmak için ürün satın alan, kullanan ve elden çıkaran bir kişi olarak tanımlamıştır. Irving vd. (2012) sorumlu tüketim davranışının üreticiler üzerindeki etkisini değerlendirmişlerdir ve buna göre tüketiciler sorumlu tüketim bilinciyle hareket ettiklerinde ortak bir bilinç oluşacak ve zararlı ürünlerden ortak bir kaçınma söz konusu olacaktır. Üreticiler tüketicilerin ortak tepkisini gördüklerinde müşteri kaybetme tehdidiyle karşı karşıya kalacağı için daha duyarlı ve sağlıklı üretim yapmaya ve toplumsal, sosyal olaylara daha duyarlı olmaya yönelecektir (Meydan, 2017, s.234). Follows ve Jobber (2000, s.738), sosyal sorumluluk sahibi tüketicinin satın alma kararı almadan önce ürün kullanımının toplum üzerindeki etkisini değerlendirdiğini belirtmiştir. Bu, 
sosyal olarak sorumlu tüketimin, tüketici değerlerini doğal, çevresel, sosyal ve ekonomik yönleriyle yansıtması gerektiğini önermektedir.

Çevrenin öneminin farkında olan ve çevre sorunlarını dikkate alan tüketiciler, tükettiği ürünlerin çevreye olan etkisini düşünerek hareket etmektedir. Ancak çevre sorunlarına karş1 duyarlı olmak her zaman çevreci tüketim sonucunu doğurmamaktadır. Autio ve Heinonen (2004, s.138) gençler üzerinde yaptıkları çalışmada gençlerin yeşil tüketime yönelik bilinçlerinin olduğunu ancak bu bilince göre davranmadıklarını tespit etmişlerdir. Tunç Husseın ve Cankül (2010, s.50) tarafından yapılan bir diğer çalışmada da, öğrencilerin büyük çoğunluğunun, çevrenin hızla tahrip olduğu endişesi taşımasına rağmen bunları ürün satın alırken, kullanırken ve kullanım sonrası davranışlarına yansıtamadıkları sonucuna ulaşmışlardır.

Ayrıca çok sayıda çalışma, demografik değişkenleri sosyal açıdan sorumlu ve çevreye duyarlı tüketim davranışlarıyla ilişkilendirmeye çalışmıştır. Bu çalışmalardan bazıları şu şekildedir: Sosyal açıdan sorumlu tüketicilerin profilini çıkarmaya yönelik çalışmalarda öncülerin (Berkowitz ve Lutterman 1968; Anderson ve Cunningham, 1972) tespit ettiği bulgular, sosyal olarak bilinçli kişilerin kadın, orta yaş öncesi, yüksek eğitim seviyesine sahip (lise mezunu), ortalamanın üzerinde sosyo-ekonomik statüye mensup olduklarını göstermektedir (Thiyagarajan ve Shanthi, 2013, s.389). Aynı şekilde Webster (1975, s.188) tarafından yapılan çalışmada da kadınların erkeklere göre daha fazla çevresel bilinçli yaşama eğilimine sahip olduğunu bulmuştur. Steger ve Witt $(1989$, s.627) yapmış olduğu çalışmasında, kadınların çevre sorumluluğuna bağlı tüketim tutumlarının ve davranışlarının erkeklerden daha fazla olduğunu tespit etmişlerdir.

Yapılan literatür incelemesi sonucunda tüketicileri sosyal sorumlu tüketime yönlendiren faydacı ve hedonik güdülerin doğrudan incelendiği bir çalışmaya rastlanamamıştır. Bundan dolayı bu çalışmada, sosyal sorumlu tüketim ile faydacı ve hedonik tüketici davranışı arasındaki iliş̧kinin sosyal olarak sorumlu tüketimin bir parçası olarak ölçülmesinin literatürdeki boşluğu doldurmaya katkıda bulunacağı düşünülmektedir.

\section{Yöntem}

\subsection{Araştırmanın Ana Kütlesi ve Örneklemi}

Araştırmanın ana kütlesini Sivas ilinde yaşayan 18 yaşından büyük tüketiciler oluşturmaktadır. Örneklemin belirlenmesinde kolayda örnekleme yöntemi esas alınmıştır. 2018 y1lı Sivas ili nüfusu 646.608 (www.tuik.gov.tr), 18 yaş üstü nüfus ise 482.272'dir. Baş (2001, s.45)'1n örneklem büyüklügü formülüne ( $\mathrm{n}=\mathrm{Nt} 2 \mathrm{pq} / \mathrm{d} 2(\mathrm{~N}-1)+\mathrm{t} 2 \mathrm{pq})$ göre $\% 5$ hata pay1yla hesaplanan örneklem büyüklügü 384 olarak bulunmuştur. Ancak hatalı ve eksik anket olma ihtimali göz önüne alınarak örnek sayısı 420 olarak belirlenmiştir. Bunlardan geçerli olan 413 anket üzerinden analiz gerçekleştirilmiştir. Veriler, katılımcılarla yüz yüze anket tekniği kullanılarak bizzat araştırmacılar tarafından 2019 yılı Şubat-Mart ayları arasında toplanmıştır. Veri toplamada yaşanan zorluklar, zaman ve maliyet gibi kısıtlar nedeniyle çalışma sadece Sivas iliyle sinırlı tutulmuştur.

\subsection{Veri Toplama Aracı}

Anket 5'li Likert tipi (1-Kesinlikle Katılmiyorum,..., 5-Kesinlikle Katıllyorum) toplam 45 ifadeden oluşmaktadır. Ankette iki farklı ölçek kullanılmıştır. Ankette yer alan "Faydacı ve Hedonik Tüketim" ifadelerini Yaşar (2017)'ın çalışmasından, "Sosyal Sorumlu Tüketim" ifadeleri ise Castano, Ortizs, Ocampo ve Leon (2016) ile Bekar (2015)'in çalışmalarından alınmıştır. Ayrıca sosyal sorumlu tüketimin alt boyutlarının adlandırılması da bu çalışmalardan olduğu gibi alınmıştır.

\subsection{Araştırmanın Modeli ve Hipotezleri}

Çalışmaya esas teşkil eden model araştırmacılar tarafından yedi değişkenli bir model şeklinde tasarlanmıştır. Başka bir ifadeyle iki bağımsız değiş̧ken beş de bağımlı değişken söz konusudur. 
Şekil 1. Araştırmanın modeli

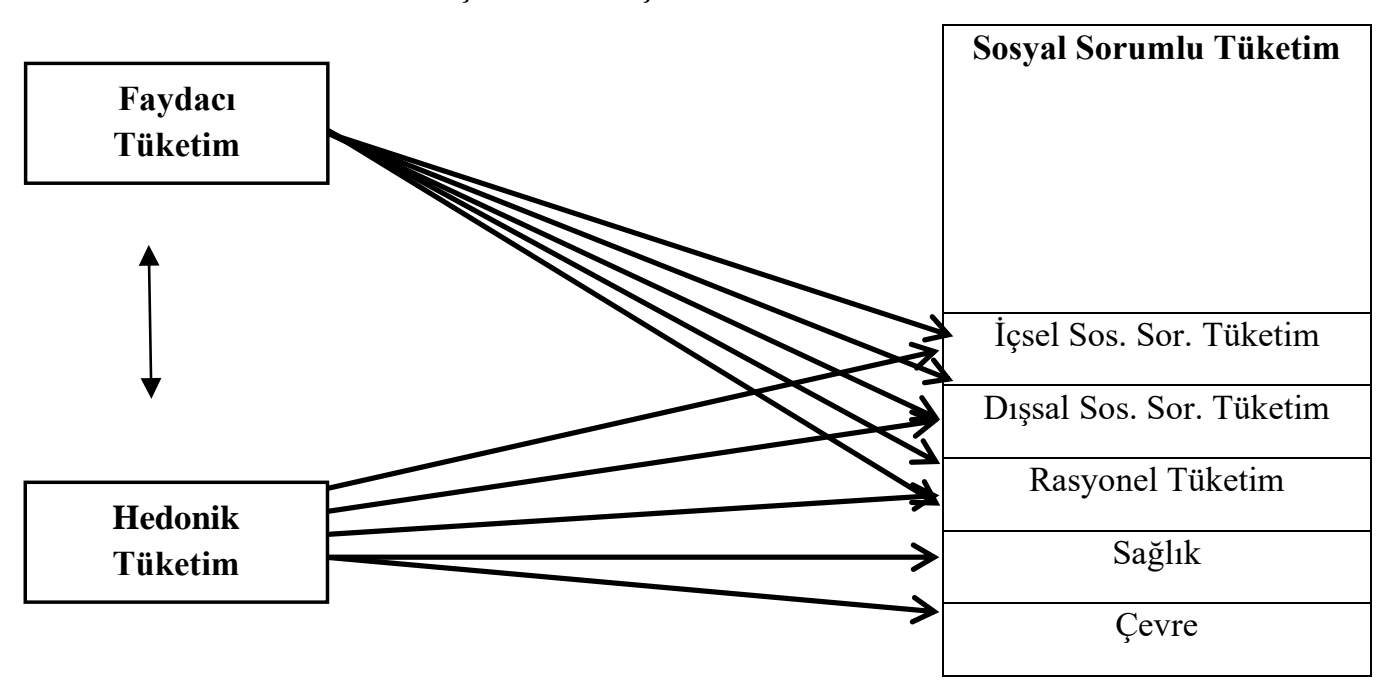

Şekil 1'deki araştırma modelinde "Faydacı Tüketim" ve "Hedonik Tüketim" bağımsız değişkenlerinden sosyal sorumlu tüketimin alt boyutlarına korelasyon ve regresyon ilişkileri görülmekte ve iki bağımsız değişkeninin de birbirlerini etkilediği varsayılmaktadır. Buna göre araştırmanın hipotezleri aşağıdaki gibi kurulmuştur:

$\mathbf{H}_{1}$ : Faydacı Tüketim ve Hedonik Tüketim arasında anlamlı ve pozitif bir ilişki vardır. vardir.

$\mathbf{H}_{2}$ : Faydacı Tüketim ile Sosyal Sorumlu Tüketim arasında anlamlı ve pozitif bir ilişki ilişki vardır.

$\mathbf{H}_{2.1}$ : Faydacı Tüketim ile İçsel Sosyal Sorumlu Tüketim arasında anlamlı ve pozitif bir ilişki vardır.

$\mathbf{H}_{2.2}$ : Faydacı Tüketim ile Dışsal Sosyal Sorumlu Tüketim arasında anlamlı ve pozitif bir

$\mathbf{H}_{2.3}$ : Faydacı Tüketim ile Rasyonel Tüketim arasında anlamlı ve pozitif bir ilişki vardır.

$\mathbf{H}_{\text {2.4: }}$ Faydacı Tüketim ile Sağlık arasında anlamlı ve pozitif bir ilişki vardır.

$\mathbf{H}_{2.5}$ : Faydacı Tüketim ile Çevre arasında anlamlı ve pozitif bir ilişki vardır. vardir.

$\mathbf{H}_{3}$ : Hedonik Tüketim ile Sosyal Sorumlu Tüketim arasında anlamlı ve pozitif bir ilişki ilişki vardır.

H3.1: Hedonik Tüketim ile İçsel Sosyal Sorumlu Tüketim arasında anlamlı ve pozitif bir ilişki vardır.

$\mathbf{H}_{3.2}$ : Hedonik Tüketim ile Dışsal Sosyal Sorumlu Tüketim arasında anlamlı ve pozitif bir

$\mathbf{H}_{3.3}$ : Hedonik Tüketim ile Rasyonel Tüketim arasında anlamlı ve pozitif bir ilişki vardır.

$\mathbf{H}_{3.4}$ : Hedonik Tüketim ile Sağlık arasında anlamlı ve pozitif bir ilişki vardır.

$\mathbf{H}_{3.5}$ : Hedonik Tüketim ile Çevre arasında anlamlı ve pozitif bir ilişki vardır.

\subsection{Kullanılan İstatistiksel Analizler}

Araştırma modelinde yer alan değişkenlerin verilerle uyumunu test etmek için Yapısal Eşitlik Modellemesi (YEM) altında Doğrulayıcı Faktör Analizi (DFA) kullanılmıştır. Daha sonra değişkenlerin tamamının verilerle uyumlu olduğu saptandıktan sonra araştırma modelinin test edilmesinde YEM altında Yol Analizi kullanılmıştır. Analizler AMOS 22 paket programıyla gerçekleştirilmiştir. 


\subsection{Analiz ve Bulgular}

\subsubsection{Doğrulayıcı Faktör Analizine Ait Bulgular}

Doğrulayıcı Faktör Analizi ile araştırmada kullanılan iki ayrı ölçeğin verilerle uyumu ve yapısal geçerliliği test edilmiştir. İlk olarak bağımsız değişkenler olan Faydacı Tüketim ve Hedonik Tüketim faktörlerinin daha sonra ise bağımlı değişkenler olan Sosyal Sorumlu Tüketim ve alt boyutlarının Doğrulayıcı Faktör Analizi ile verilerle uyumu test edilmiştir.

\subsubsection{Faydacı Tüketim ve Hedonik Tüketim Değişsenlerinin DFA Sonuçları}

18 ifadeden oluşan Faydacı ve Hedonik Tüketim ölçeği DFA'ya Tabi tutulmuştur. Şekil 2'de Faydacı ve Hedonik Tüketim değişkenlerinin AMOS diyagramı görülmektedir.

Şekil 2. Faydacı ve Hedonik tüketim değişkenlerinin AMOS diyagramı

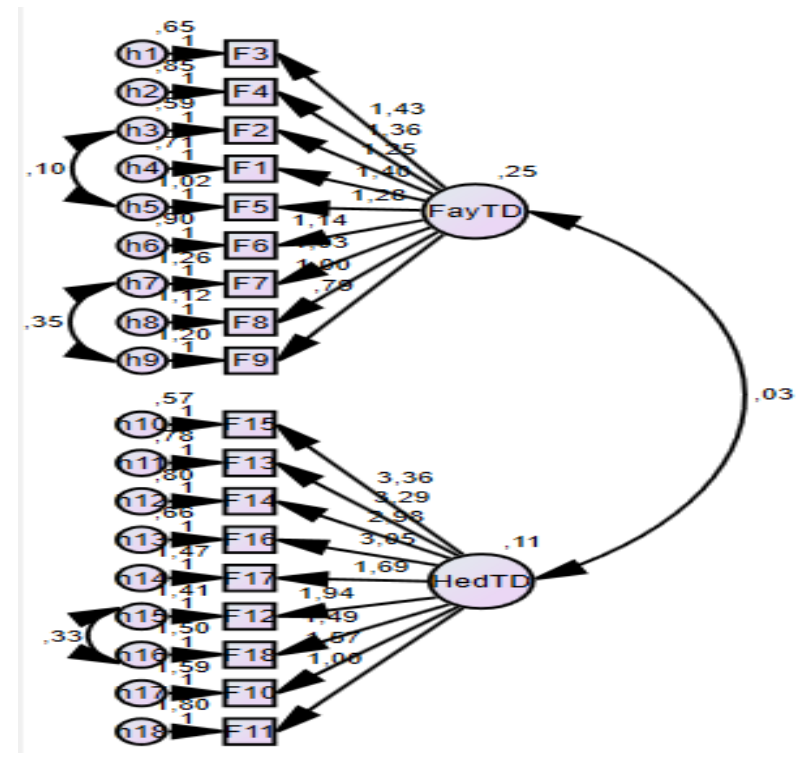

Buna göre 18 ifadeden oluşan ölçeğin DFA sonuçları Tablo 1'deki gibidir. Tablo 1'deki sonuçlara göre iki bağımsız değişkenin uyum indeksleri kabul edilebilir uyum göstermektedir. Dolayısıyla, ortaya konulan iki değişkenli yapının geçerliliği ve gözlenen değerlerle uyumu doğrulayıcı faktör analizi ile de teyit edilmiştir.

Tablo 1. Faydacı ve hedonik tüketim değişkenlerinin uyum iyiliği değerleri

\begin{tabular}{|c|c|c|c|c|}
\hline & $\begin{array}{c}\text { Model } \\
\text { Uyum } \\
\text { Kriterleri }\end{array}$ & $\begin{array}{l}\text { İyi Uyum } \\
\text { Değerleri }\end{array}$ & $\begin{array}{l}\text { Kabul Edilebilir } \\
\text { Uyum Değerleri }\end{array}$ & $\begin{array}{c}\text { Faydacı ve } \\
\text { Hedonik } \\
\text { Tüketim }\end{array}$ \\
\hline 1. & CMIN/SD & $\chi^{2} / \mathrm{df} \leq 3$ & $\chi^{2} / \mathrm{df} \leq \mathbf{5}$ & $2,847 \leq 3$ \\
\hline 2. & IFI & $\mathbf{0 , 9 5} \leq \mathrm{IFI}$ & $\mathbf{0 , 9 0} \leq \mathrm{IFI}$ & $0,90 \leq \mathbf{0 , 9 0 2}$ \\
\hline 3. & CFI & $0,97 \leq \mathrm{CFI}$ & $0,95 \leq \mathrm{CFI}$ & $0,95 \leq \mathbf{0 , 9 0 7}$ \\
\hline 4. & GFI & $\mathbf{0 , 9 0} \leq \mathrm{GFI}$ & $\mathbf{0 , 8 5} \leq \mathrm{GFI}$ & $0,85 \leq \mathbf{0 , 9 1 1}$ \\
\hline 5. & RMSEA & $\mathbf{0 , 0 5} \geq \mathrm{RMSEA}$ & $\mathbf{0 , 0 8} \geq$ RMSEA & $0,08 \geq \mathbf{0 , 0 6 7}$ \\
\hline
\end{tabular}

\subsubsection{Sosyal Sorumlu Tüketim Ölçeğinin Alt Boyutlarının DFA Sonuçları}

Beş alt boyuttan oluşan Sosyal Sorumlu Tüketim ölçeği DFA'ya tabi tutulmuştur. Şekil 3'de beş alt boyutlu ölçeğin AMOS diyagramı görülmektedir. Tablo 2'de ise İçsel Sosyal Sorumlu Tüketim, Dışsal Sosyal Sorumlu Tüketim, Rasyonel Tüketim, Sağlık ve Çevre boyutlarından oluşan toplam 27 maddelik ölçeğe ait DFA sonuçları görülmektedir. 
Şekil 3. Sosyal sorumlu tüketim değişkenlerinin AMOS diyagramı

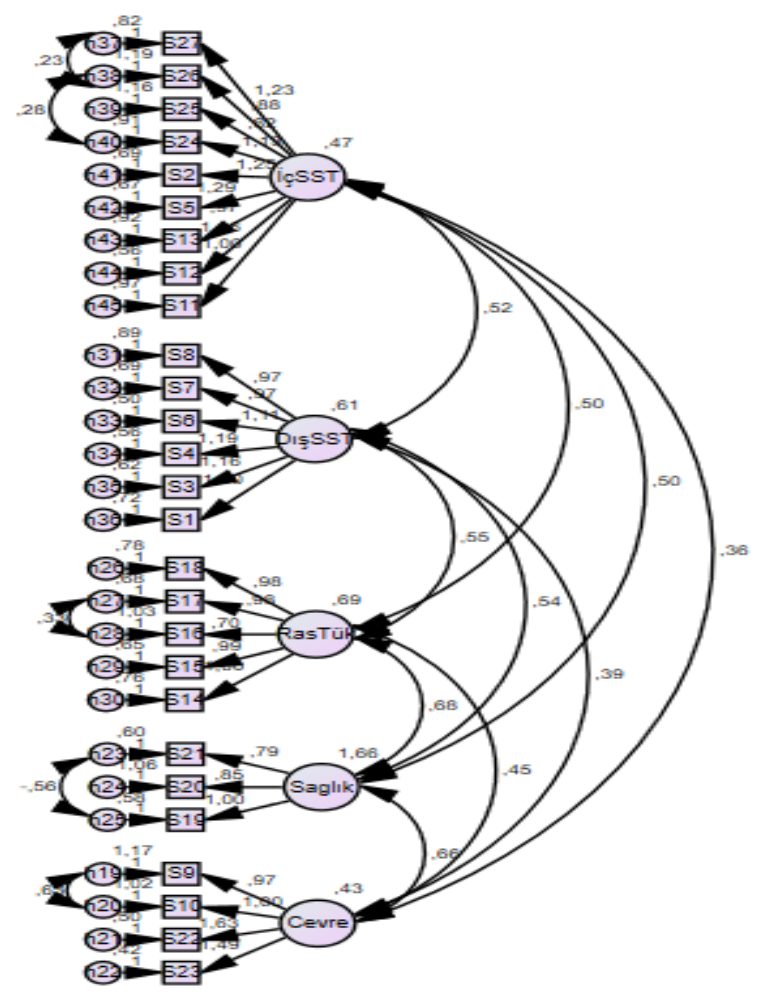

Tablo 2'deki sonuçlara göre beş değişkenin uyum indeksleri kabul edilebilir derecede uyum göstermektedir. Dolayısıyla, ortaya konulan beş değişkenli yapının geçerliği ve gözlenen değerlerle uyumu doğrulayıcı faktör analizi ile de teyit edilmiştir.

Tablo 2. Sosyal Sorumlu Tüketim Değişkenlerinin Uyum İyiliği Değerleri

\begin{tabular}{ccccc}
\hline & $\begin{array}{c}\text { Model } \\
\text { Uyum } \\
\text { Kriterleri }\end{array}$ & $\begin{array}{c}\text { Iyi Uyum } \\
\text { Değerleri }\end{array}$ & $\begin{array}{c}\text { Kabul Edilebilir } \\
\text { Uyum Değerleri }\end{array}$ & $\begin{array}{c}\text { Sosyal } \\
\text { Sorumlu } \\
\text { Tüketim }\end{array}$ \\
\hline 1. & CMIN/SD & $\chi^{2} / \mathrm{df} \leq \mathbf{3}$ & $\chi^{2} / \mathrm{df} \leq \mathbf{5}$ & $\mathbf{3 , 0 0 6} \leq \mathbf{5}$ \\
$\mathbf{2 .}$ & IFI & $\mathbf{0 , 9 5} \leq \mathrm{IFI}$ & $\mathbf{0 , 9 0} \leq \mathrm{IFI}$ & $0,90 \leq \mathbf{0 , 9 0 4}$ \\
$\mathbf{3 .}$ & CFI & $\mathbf{0 , 9 7} \leq$ CFI & $\mathbf{0 , 9 5} \leq$ CFI & $0,95 \leq \mathbf{0 , 9 0 5}$ \\
$\mathbf{4 .}$ & GFI & $\mathbf{0 , 9 0} \leq$ GFI & $\mathbf{0 , 8 5} \leq$ GFI & $0,85 \leq \mathbf{0 , 8 6 8}$ \\
$\mathbf{5 .}$ & RMSEA & $\mathbf{0 , 0 5} \geq$ RMSEA & $\mathbf{0 , 0 8} \geq$ RMSEA & $0,08 \geq \mathbf{0 , 0 7 0}$ \\
\hline
\end{tabular}

İki ayrı ölçeğe ayrı ayrı olarak uygulanan DFA sonucunda ölçeklerin ve alt boyutlarının, verilerle kabul edilebilir derecede uyum gösterdikleri tespit edilmiştir. Değişkenlerin tamamının kabul edilebilir derecede uyum göstermeleri saptandıktan sonra genel modelin Yol Analizi ile test edilmesine geçilmiştir.

\subsubsection{Yol Analizine İlişkin Sonuçlar}

Araştırmacılar tarafından tasarlanan, iki bağımsız ve beş bağımlı değişkenden oluşan araştırma modelinin ilk hali Şekil 4'te görüldügü gibidir. 
Şekil 4. Araştırma modelinin ilk halinin AMOS diyagramı

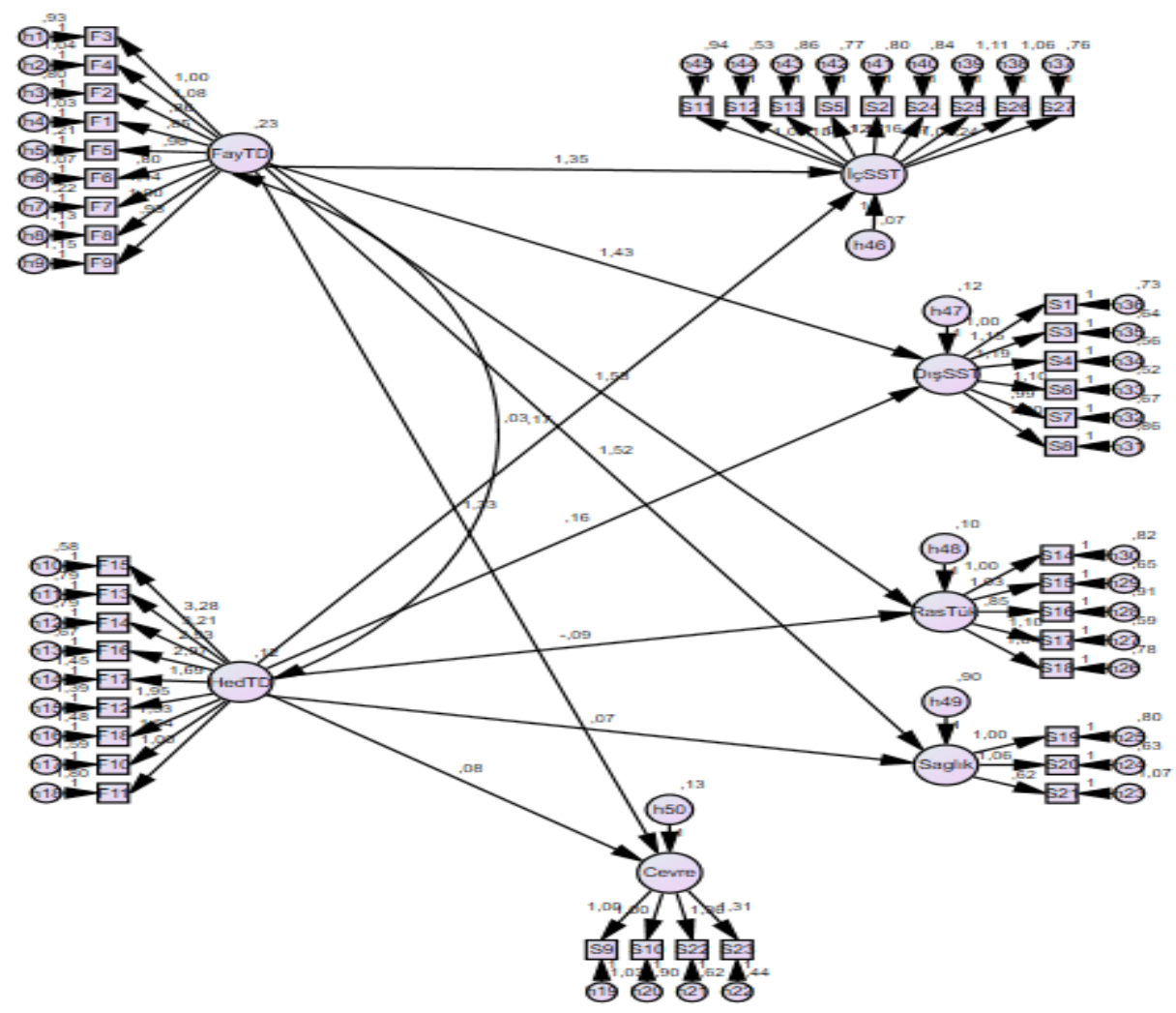

Araştırma modelinin Yol Analizi soncundaki uyum iyiliği değerleri Tablo 3'de görüldüğü gibidir. Tablo 3'e göre modelin ilk halinin uyum iyiliği değerleri kabul edilebilir aralıklarda değildir. Dolayısıyla model anlamsızdır. Bunun nedeni ise Tablo 4'te görüldügü gibi modeldeki regresyon ilişkilerini gösteren yollardan bazılarının anlamsız olmasıdır.

Tablo 3. Genel modelin yol analizi uyum iyiliği değerleri

\begin{tabular}{ccccc}
\hline & $\begin{array}{c}\text { Model Uyum } \\
\text { Kriterleri }\end{array}$ & $\begin{array}{c}\text { İyi Uyum } \\
\text { Değerleri }\end{array}$ & $\begin{array}{c}\text { Kabul Edilebilir } \\
\text { Uyum Değerleri }\end{array}$ & $\begin{array}{c}\text { Araştırma } \\
\text { Modeli }\end{array}$ \\
\hline $\mathbf{1 .}$ & CMIN/SD & $\chi^{2} / \mathrm{df} \leq \mathbf{3}$ & $\chi^{2} / \mathrm{df} \leq \mathbf{5}$ & $\mathbf{3 , 2 0 5} \leq \mathbf{5}$ \\
$\mathbf{2 .}$ & IFI & $\mathbf{0 , 9 5} \leq$ IFI & $\mathbf{0 , 9 0} \leq$ IFI & $0,90 \leq \mathbf{0 , 7 5 9}$ \\
$\mathbf{3 .}$ & CFI & $\mathbf{0 , 9 7} \leq$ CFI & $\mathbf{0 , 9 5} \leq$ CFI & $0,95 \leq \mathbf{0 , 7 5 7}$ \\
$\mathbf{4 .}$ & GFI & $\mathbf{0 , 9 0} \leq$ GFI & $\mathbf{0 , 8 5} \leq$ GFI & $0,85 \leq \mathbf{0 , 7 4 3}$ \\
$\mathbf{5 .}$ & RMSEA & $\mathbf{0 , 0 5} \geq$ RMSEA & $\mathbf{0 , 0 8} \geq$ RMSEA & $0,08 \geq \mathbf{0 , 0 7 3}$ \\
\hline
\end{tabular}

Tablo 4'teki regresyon katsayılarına göre modelde Hedonik Tüketim bağımsız değişkeninden İçsel Sosyal Sorumlu Tüketim ( $\mathrm{p}=0,094>0,001)$, Dışsal Sosyal Sorumlu Tüketim $(\mathrm{p}=0,160>0,001)$, Rasyonel Tüketim $(\mathrm{p}=0,467>0,001)$, Sağlı $(\mathrm{p}=0,713>0,001)$ ve Çevre $(\mathrm{p}=0,474>0,001)$ bağımlı değişkenlerine giden yolların anlamsız olduğu ve analizden çıkarılması gerektiği görülmektedir. Çıkarma ilk olarak p değeri en yüksek olandan (anlamlılık düzeyi en düşük olandan) başlayıp tüm anlamsız ilişkiler ortadan kalkana dek büyükten küçüğe doğru bir sıralama ile tekrarlanır (Meydan ve Şeşen, 2015, s.109). Dolayısıyla önce Hedonik Tüketim değişkeninden Sağlık değişkenine giden yolun analizden çıkarılması gerekmektedir.

Tablo 4. Değişkenlerin regresyon katsayıları

\begin{tabular}{lllllll}
\hline \multicolumn{1}{c}{ Yollar } & & & Tahmin & $\begin{array}{l}\text { Standart } \\
\text { Hata }\end{array}$ & $\begin{array}{l}\text { Ki Kare } \\
\text { Değeri }\end{array}$ & $\boldsymbol{p}$ \\
\hline İçST & $<---$ & FayTD & 1,346 &, 184 & 7,319 & $* * *$ \\
D1şSST & $<---$ & FayTD & 1,425 &, 187 & 7,616 & $* * *$ \\
\hline
\end{tabular}




\begin{tabular}{lllllll}
\hline \multicolumn{1}{c}{ Yollar } & & & Tahmin & $\begin{array}{l}\text { Standart } \\
\text { Hata }\end{array}$ & $\begin{array}{l}\text { Ki Kare } \\
\text { Değeri }\end{array}$ & $\boldsymbol{p}$ \\
\hline RasTük & $<---$ & FayTD & 1,529 &, 202 & 7,585 & $* * *$ \\
Saglık & $<---$ & FayTD & 1,523 &, 220 & 6,933 & $* * *$ \\
Cevre & $<---$ & FayTD & 1,325 &, 182 & 7,271 & $* * *$ \\
İçSST & $<---$ & HedTD &, 173 &, 103 & 1,672 &, 094 \\
DişSST & $<---$ & HedTD &, 160 &, 114 & 1,406 &, 160 \\
RasTük & $<---$ & HedTD &,- 085 &, 117 &,- 727 &, 467 \\
Saglık & $<---$ & HedTD &, 071 &, 193 &, 368 &, 713 \\
Cevre & $<---$ & HedTD &, 078 &, 109 &, 716 &, 474 \\
\hline
\end{tabular}

Analizden en yüksek p değerine sahip yollar sırayla çıkarılmış ancak ilk analizde anlamsız olan yolların yine anlamsız olarak kaldığı görülmüştür. Dolayısıyla hedonik tüketimden bağımlı değişkenlere doğru çizilen tüm yollar anlamsızdır. Başka bir ifadeyle H3, H3.1, H3.2, H3.3, H3.4 ve H3.5 hipotezleri reddedilmiştir. Bu bağlamda Hedonik Tüketim' in Sosyal Sorumlu Tüketim ve alt boyutları olan İçsel Sosyal Sorumlu Tüketim, Dışsal Sosyal Sorumlu Tüketim, Rasyonel Tüketim, Sağlık ve Çevre değişkenleri üzerinde anlamlı bir etkisi olmadığı söylenebilir.

Analizden anlamsız yollar çıkarıldıktan sonra araştırma modelinin AMOS diyagramı Şekil 5'te görüldüğü gibidir.

Şekil 5. Araştırma modelinin son halinin AMOS diyagramı

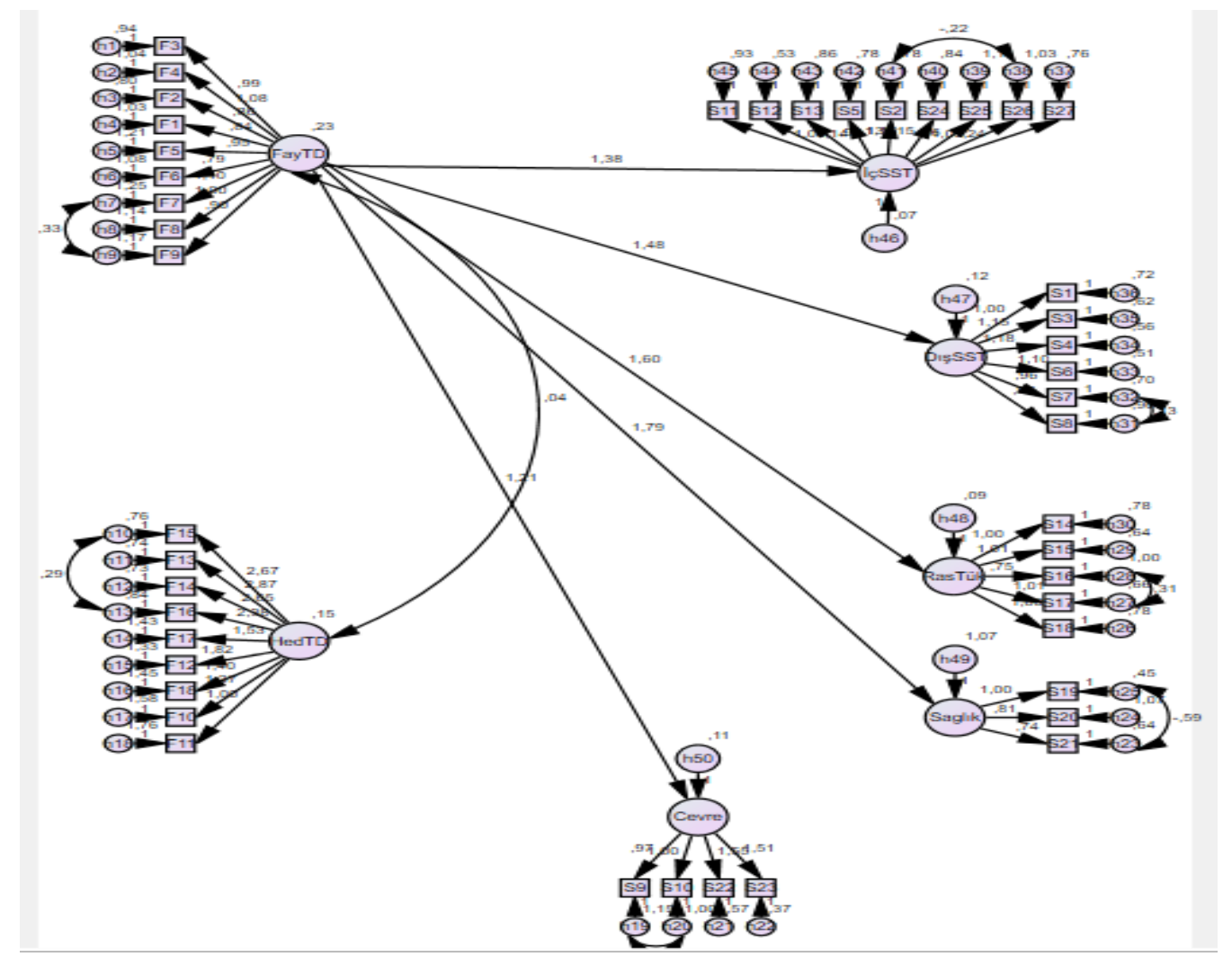

Araştırma modelinin son halinin uyum iyiliği değerleri ise Tablo 5’te görüldüğü gibidir. 
Tablo 5. Genel modelin yol analizi uyum iyiliği değerleri

\begin{tabular}{lcccc}
\hline & $\begin{array}{c}\text { Model Uyum } \\
\text { Kriterleri }\end{array}$ & $\begin{array}{c}\text { Iyi Uyum } \\
\text { Değerleri }\end{array}$ & $\begin{array}{c}\text { Kabul Edilebilir } \\
\text { Uyum Değerleri }\end{array}$ & $\begin{array}{c}\text { Araştırma } \\
\text { Modeli }\end{array}$ \\
\hline 1. & CMIN/SD & $\chi^{2} / \mathrm{df} \leq \mathbf{3}$ & $\chi^{2} / \mathrm{df} \leq \mathbf{5}$ & $\mathbf{2 , 5 8 0 \leq 5}$ \\
2. & IFI & $\mathbf{0 , 9 5} \leq$ IFI & $\mathbf{0 , 9 0} \leq$ IFI & $0,90 \leq \mathbf{0 , 9 0 9}$ \\
3. & CFI & $\mathbf{0 , 9 7} \leq$ CFI & $\mathbf{0 , 9 5} \leq$ CFI & $0,95 \leq \mathbf{0 , 9 1 1}$ \\
4. & GFI & $\mathbf{0 , 9 0} \leq$ GFI & $\mathbf{0 , 8 5} \leq$ GFI & $0,85 \leq \mathbf{0 , 8 9 2}$ \\
$\mathbf{5 .}$ & RMSEA & $\mathbf{0 , 0 5} \geq$ RMSEA & $\mathbf{0 , 0 8} \geq$ RMSEA & $0,08 \geq \mathbf{0 , 0 6 2}$ \\
\hline
\end{tabular}

Tablo 5'teki sonuçlara göre modelin son halinin uyum iyiliği değerleri kabul edilebilir aralıktadir. Başka bir ifadeyle araştırmacılar tarafından tasarlanan modelin verilerle uyumlu olduğu ve modelin son halinin istatistiksel olarak anlamlı ve geçerli olduğu söylenebilir. Bununla birlikte modeldeki regresyon ilişkilerini gösteren yolların anlamlılığ için Tablo 6'daki regresyon katsayılarına da bakmak gerekmektedir.

Tablo 6. Değişkenlerin regresyon katsayıları

\begin{tabular}{lllllll}
\hline \multicolumn{1}{c}{ Yollar } & & & Tahmin & $\begin{array}{l}\text { Standart } \\
\text { Hata }\end{array}$ & $\begin{array}{l}\text { Ki Kare } \\
\text { Değeri }\end{array}$ & $\boldsymbol{p}$ \\
\hline İçSST & $<---$ & FayTD & 1,234 &, 164 & 7,535 & $* * *$ \\
DişSST & $<---$ & FayTD & 1,244 &, 159 & 7,805 & $* * *$ \\
RasTük & $<---$ & FayTD & 1,458 &, 184 & 7,909 & $* * *$ \\
Saglik & $<---$ & FayTD & 1,556 &, 206 & 7,555 & $* * *$ \\
Cevre & $<---$ & FayTD & 1,048 &, 148 & 7,063 & $* * *$ \\
\hline
\end{tabular}

Tablo 6'ya göre modelde kurulan tüm yollar istatistiksel olarak anlamlıdır. Buna göre Faydacı Tüketimden İçsel Sosyal Sorumlu Tüketim ( $\chi 2=7,535 ; p<0,001)$, Dışsal Sosyal Sorumlu Tüketim $(\chi 2=7,805 ; \mathrm{p}<0,001)$, Rasyonel Tüketim $(\chi 2=7,909 ; \mathrm{p}<0,001)$, Sağlık $\left(\chi^{2}=7,555\right.$; $\mathrm{p}<0,001)$ ve Çevre $(\chi 2=7,063 ; \mathrm{p}<0,001)$ bağımlı değişkenlerine giden yolların tamamı istatistiksel olarak anlamlı ve geçerlidir. Başka bir ifadeyle faydacı tüketimin tüketicilerin sosyal sorumlu tüketim davranışları üzerinde pozitif ve anlamlı bir etkiye sahiptir. Dolayısıyla H2, H2.1, $\mathrm{H} 2.2, \mathrm{H} 2.3, \mathrm{H} 2.4$ ve $\mathrm{H} 2.5$ hipotezleri kabul edilmiştir.

Yapısal Eşitlik Modellemesi, analiz sonuçlarında uyum iyiliği ve regresyon katsayıları dışında değişkenler arasındaki korelasyon ilişkilerini gösteren bir sonuç da vermektedir. Buna göre Tablo 7'de modelde var olan Faydacı Tüketim ve Hedonik Tüketim arasındaki korelasyon iliş̧kisi ve katsayısı dışında modelde yapılan modifikasyonların da korelasyon ilişkileri ve katsayıları görülmektedir. Maddeler arasında yapılan modifikasyonlar da, doğrudan maddeler arasında değil maddelerin hata terimleri arasında modifikasyon kurulmaktadır. Dolayısıyla Tablo 7'de de görüleceği üzere değişkenlerin kendi aralarındaki ilişki hariç, diğer ilişkiler hata terimleri üzerinde gösterilmiştir.

Tablo 7. Değişkenler ve alt maddeleri arasındaki korelasyon katsayıları

\begin{tabular}{|c|c|c|c|c|c|c|}
\hline İlişkiler & & & Tahmin & İlişkiler & & Tahmin \\
\hline FayTD & $\langle-\rangle$ & HedTD & , 199 & h23 & $<-->$ h25 & $-1,104$ \\
\hline $\mathrm{h} 7$ & $\langle--\rangle$ & h9 & 257 & h27 & $<-->$ h28 & ,361 \\
\hline h10 & $\langle-->$ & h13 & ,367 & h31 & $<-->$ h32 & ,203 \\
\hline h19 & $\langle-->$ & h20 & 577 & h38 & $<-->h 41$ & ,488 \\
\hline
\end{tabular}

Tablo 7'ye göre faydacı tüketim ile hedonik tüketim arasında korelasyon ilişkisi vardır ve katsayısı 0,199'dur. Yani iki değişken birbirilerini yaklaşık olarak \%20 oranında etkilemektedir. Dolayısıyla bu sonuca göre H1 hipotezi de kabul edilmiştir. 


\section{Sonuç ve Öneriler}

Faydacı ve hedonik güdülerin tüketicilerin sosyal sorumlu tüketim davranışları üzerindeki etkisi ortaya koymak amacıyla yapılan bu araştırma kapsamında; faydacı ve hedonik tüketim güdülerinin sosyal sorumlu tüketim ölçeğinin alt boyutları İçsel Sosyal Sorumlu Tüketim, Dışsal Sosyal Sorumlu Tüketim, Rasyonel Tüketim, Sağlık ve Çevre gibi bağımlı değişkenleri üzerindeki etkisini tespit etmek amaciyla yapilan Yol analizi sonucunda Hedonik Tüketim güdüsünün içsel sosyal sorumlu tüketim, dışsal sosyal sorumlu tüketim, rasyonel tüketim, sağlik ve çevre değişkenleri üzerinde anlamlı bir etkisinin olmadığ tespit edilmiştir. Bu sonuç Clement vd. (2009) tarafından yapılan çalışmanın sonuçlarıyla örtüşmektedir. Çalışma sonucunda hedonik satın alma davranışının duygusal öğeler içerdiği, tüketicilerin genellikle sembolik sebeplerden dolayı satın aldığını ve yüksek tüketim riski içerdiğini belirtilmiştir. Dolayısıyla hedonik güdülerin etkisi ile satın alma davranışında bulunan tüketicinin sosyal sorumluluğu göz ardı ettiği söylenebilir.

Faydacı Tüketim güdüsünün ise İçsel Sosyal Sorumlu Tüketim, Dışsal Sosyal Sorumlu Tüketim, Rasyonel Tüketim, Sağlık ve Çevre gibi sosyal sorumlu tüketimin alt boyutları üzerinde pozitif ve anlamlı bir etkiye sahip olduğu sonucuna ulaşılmıştır. Follows ve Jobber (2000, s.738) tarafından yapılan çalışmada mevcut çalışmadaki sonucu desteklemektedir. Yapılan çalışmada sosyal sorumluluk sahibi tüketicinin satın alma kararı almadan önce ürün kullanımının toplum üzerindeki etkisini değerlendirdiğini belirtmiştir.

Son olarak araştırma modelinde bağımsız değişkenler olarak yer alan Faydacı Tüketim ve Hedonik Tüketim değişkenlerinin arasındaki korelasyon ilişkisi test edilmiş ve iki değişken arasında pozitif ve anlamlı bir ilişki olduğu bulunmuştur. Başka bir ifadeyle iki değişkenin birbirilerini yaklaşık olarak \%20 oranında etkilediği görülmüştür.

Araştırma kapsamında şu önerilerde bulunulabilir:

- Aşırı tüketim ya da gösterişçi tüketim yerine sosyal sorumlu tüketim davranışı tüketiciler tarafından benimsenmelidir.

- Hükümet, kamu kurumlar ve STK'lar tarafindan sosyal sorumlu tüketim noktasında tüketicileri bilinçlendirmek için çeşitli bilgilendirme faaliyetleri yapilmalıdir.

- Tüketicilerin sosyal sorumluluk bilinciyle hareket etmesi ve bunu da bir alışkanlık haline getirmesi için gerekli çalı̧̧maların yapılması gerekmektedir.

- Daha iyi bir gelecek için daha az ve bilinçli tüketim yapmak çoğu birey tarafından kabul edilmeli ve sade yaşam tarzı tüketiciler tarafından daha çok benimsenmelidir.

- Sosyal sorumlu tüketim davranışlarının özendirilmesi ve desteklenmesi için ulusal ve uluslararası politikalar oluşturulmalı böylece tüketicilerin hem kendi davranışlarını sosyal sorumluluk noktasında değiştirmeleri mümkün olacak hem de tüketiciler işletmeleri daha sorumlu davranmaya yönlendireceklerdir.

Araştırmanın sadece Sivas ili şehir merkezinde yapılması, zaman ve maliyet gibi zorluklardan dolayı örneklem sayısının fazla olmaması, seçilen örneklem yöntemi ve kullanılan istatistiksel teknikler bu çalışmanın kısıtlarını oluşturmaktadır. Araştırmacıların gelecekte daha geniş kapsamlı, daha büyük sayıda örneklem gruplarıyla daha farklı istatistiksel teknikler kullanarak yapacakları araştırmalarda bu konuda daha iyi sonuçlara ulaşılması mümkün olacaktır.

\section{Kaynakça}

Adomaviciute, K. (2013). Relationship between utilitarian and hedonic consumer behavior and socially responsibl econsumption. Economics and Management, 18 (4), 754-760. 
Aksoy, R. ve Erdoğan, E. (2008). Yeşil ürün tercih eden tüketici özellikleri: KDZ. Ereğli’sinde tüketiciler üzerine bir inceleme, 13.Ulusal Pazarlama Kongresi, Çukurova Üniversitesi, Adana.

Autio, M. ve Heinonen V. (2004). To consume or not to consume? young people's environmentalism in the affluent finnish society. Young, 12(2),137-153.

Babin, B. J.,Darden, W. R. ve Griffin, M. (1994). Work and/or fun: measuring hedonic and utilitarian shopping value. Journal of Consumer Research, 20 (4), 644-656.

Baş T., (2001), “Anket”, Ankara: Seçkin Yayıncılık.

Bekar, S. (2015).Sosyal sorumlu tüketim davranışının ölçümü ve değerlendirilmesi üzerine bir uygulama (Yayınlanmamış yüksek lisans tezi). Atatürk Üniversitesi, Erzurum.

Buğday, E.B. (2015). Bilinçli tüketici ölçeği geliştirme çalışması (Yayınlanmamış doktora tezi). Hacettepe Üniversitesi, Ankara.

Buhrman, T. (2002). "Effectsof hedonic and utilitarian shopping satisfactionon mall consumption",University of North Texas.

Carpenter, J. M.,Moore, M. ve Fairhurst, A. E. (2005). Consumer shopping value for retail brands. Journal of Fashion Marketing and Management, 9(1), 43-53.

CastanoLida E.V.,Ortizs, Jesus P., Ocampo, Sebastian D. ve Leon, William F.D. (2016). "Socially responsible consumption: an application in colombia. Business Ethics, 25 (4), 460-481.

Clement, M., Fabel, S. ve Schmidt-Stolting, C. (2009). Diffusion of hedonic goods: a literature review. International Journal on Media Management, 8(4), 155-163.

Çabuk, S.ve Nakiboğlu, B. (2003). Çevreci pazarlama ve tüketicilerin çevreci tutumlarının satın alma davranışlarına etkileri ile ilgili bir uygulama. Çukurova Üniversitesi İ̈BF Dergisi, 12(12), 39-54.

Dahl, D. W.,Honea, H. Ve Manchanda, R.V. (2003). The nature of self-reported guilt in consumption contexts. Marketing Letters, 14(3), 159-171.

Dursun, İ., Tümer Kabadayı, E. ve Tuğer, A. T. (2016).Sorumlu tüketim: neden? nasıl?. M. Babaoğul, A. Şener ve E. Buğday ( Ed), Tüketici yazıları içinde (ss. 9-39). Ankara: Hacettepe Üniversitesi Tüpadem.

Fırat, A. ve Aydın, A. E. (2016). Hedonik ve faydacı alışveriş davranışı üzerine bir araştırma. Uluslararası Sosyal Araştırmalar Dergisi, 9(43),1840-1846.

Follows, S. B. ve Jobber, D. (2000). Environmentally responsible purchase behaviour: a test of a consumer model. European Journal of Marketing, 34(5/6), 723-747.

For Socially and Environmentally Responsible Choices, https://equiterre.org,(Erişim Tarihi:10.01.2019).

Francois-Lecompte, A. ve Roberts, J.A. (2006). Developing a measure of socially responsible consumption in france, Marketing Management Journal, 16(2), 50-66.

Hirschman, E. C. ve Holbrook, M. B., (1982). Hedonic consumption: emerging concepts. methods and propositions. Journal of Marketing, 46, 92-101.

Holbrook, M. B. ve Hirschman, E. C. (1982). The experiential aspects of consumption: consumer fantasies, feelings, and fun. Journal of Consumer Research, 9(2), 132-140.

http://www.tuik.gov.tr/PreTablo.do?alt_id=1059 (E.T.:01.04.2020). 
Irani, N. ve Hanzaee, K. H. (2011). The effects of 1ranian consumers' buying tendencies on utilitarian and hedonic shopping value. African Journal of Business Management, 5(17), 7449-7460.

Meydan, B. (2017). Etik tüketicinin kozmetik ürünü satın alma kararı: promethee tekniği ile bir uygulama. Uluslararası Akademik Yönetim Bilimleri Dergisi, 3 (4), 233-259.

Meydan, C. H. ve Şeşen, H. (2015). Yapısal eşitlik modellemesi amos uygulamaları. Ankara: Detay Yayıncilık.

Mohr, L.A.,Webb, D.J. ve Harris, K.E. (2001). Do consumers expect companies to be socially responsible? the impact of corporate social responsibility on buying behavior. Journal of Consumer Affair, 35(1), 45-72.

Özgül, E. (2011). Tüketicilerin sosyo-demografik özelliklerinin hedonik tüketim ve gönüllü sade yaşam tarzları açısından değerlendirilmesi. Ege Akademik Bakış Dergisi, 11(1), 25-38.

Pagiaslis, A.ve Krontalis, A.K.(2014). Green Consumption Behavior Antecedents: Environmental Concern, Knowledge, and Beliefs. Psychol. Mark. 31,335-348.

Roberts, J.A. (1996). Will the real socially responsible consumer please step forward?. Business Horizons, 39(1), 79-83.

Saydan, R. ve Kanıbir, H. (2001). Üniversiteli tüketicilerin çevreci tüketim tutumları ve satın alma davranışlarına etkileri. H. Ü. İktisadi ve İdari Bilimler Fakültesi Dergisi, 25(2), 213-242.

Sayraç, N.(2016).Aile ve bireysel değerlerin sorumlu tüketim bilinci üzerindeki etkisi (Yayınlanmamış yüksek lisans tezi). İstanbul Ticaret Üniversitesi, İstanbul.

Steger, M. A. E. ve Witt, S. L. (1989). Gender differences in environmental orientations: A comparison of publics and activists in canada and the us. The Western Political Quarterly, 42: 627-649.

Süygün, M. S. (2015). Küresel işletmelerde etik bir yaklaşım: adil ticaret. Çă̆ Üniversitesi Sosyal Bilimler Dergisi, 12(2),48-63.

Szmigin, I. ve Carrigan, M. (2006). Exploring the dimensions of ethical consumption. European Advances in Consumer Research, 7, 608-613.

Şüküroğlu, V. K.(2018). Sürdürülebilirlik bağlamında tüketici vatandaş sorumluluğu. The Journal of Academic Social Science Studies, 65, 451-470.

Tangney, J.P. ve Dearing, R. (2002). Shame and guilt. New York: Guilford.

Thiyagarajan, S. ve Shanthi, P. (2013). Social responsible consumer behaviour and its effectiveness on advertisiments in india. Sociology Study, 3(5),387-394.

Tunç Husseın, A. ve Cankül, D. (2010). Üniversite öğrencilerinin yeşil pazarlama faaliyetleri kapsamında çevreye ilişkin davranışlarını belirlemeye yönelik bir araştırma. Ticaret ve Turizm Ĕ̈itim Fakültesi Dergisi, 1, 50-67.

Urminsky, O. ve Kivetz, R. (2003). "Reconciling impulsiveness with self-control: explaining differential. Advances in Consumer Research, 31, 358-361.

Webb, D. J.,Mohr, L. A. ve Harris, K. E. (2008). A re-examination of socially responsible consumption and its measurement. Journal of Business Research, 61(2), 91-98.

Webster, Jr. F. E. (1975). "Determining the characteristics of the socially conscious consumer. Journal of Consumer Research, 2, 188-196.

Wilkes, R. E. (1978). Fraudulent behavior by consumers. Journal of Marketing, 67-75. 
Yaşar, M. (2017). Hedonik ve faydacı tüketim bağlamında tüketici davranışlarının incelenmesi:

Gençlerin hedonik tüketim eğilimlerini belirlemeye yönelik bir araştırma (Yayınlanmamış doktora tezi). Dumlupınar Üniversitesi, Kütahya.

\section{ETIKK ve BİLIMSEL İLKELER SORUMLULUK BEYANI}

$\mathrm{Bu}$ çalışmanın tüm hazırlanma süreçlerinde etik kurallara ve bilimsel atıf gösterme ilkelerine riayet edildiğini yazar(lar) beyan eder. Aksi bir durumun tespiti halinde Afyon Kocatepe Üniversitesi Sosyal Bilimler Dergisi'nin hiçbir sorumluluğu olmayıp, tüm sorumluluk makale yazarlarına aittir. 